\title{
Fredrik Pacius ja Porthanin perintö: kantaatti Henrik Gabriel Porthan (1860)
}

\author{
Hannu Salmi
}

Henrik Gabriel Porthan kuoli vuonna 1804. Uutta vuosisataa hän ehti nähdä vain muutaman vuoden eikä tietenkään voinut aavistaa sitä, miten nopeasti maailma muuttuisi. Porthan oli kartuttanut Turun Akatemian kirjastoa uutterasti 40000 niteen kokoelmaksi, mutta valtaosa tästä elämäntyöstä levisi tuhkana Turun ympäristöön järkyttävän tulipalon seurauksena 23 vuotta myöhemmin. Tutkimuksissaan Porthan oli monipuolinen uushumanismin edustaja: hän kirjoitti historiasta, kansanperinteestä ja suomen kielestä sekä tutki retoriikkaa, filosofiaa ja psykologiaa. Tämä työ oli hänen perintönsä, jota tutkittiin tarkoin 1800-luvulla, ja Porthanin kirjoituksista etsittiin viestejä modernisoituvalle kansakunnalle. Ennen kuolemaansa Porthan uskoi henkilökohtaiset paperinsa ystävälleen Jacob Tengströmille. Vasta kolmetoista vuotta Porthanin kuoleman jälkeen Tengström sulki Porthanin kirjeitä, Aurora-seuran pöytäkirjoja ja muuta aineistoa kirstuun, jonka saisi avata vasta vuonna $1900 .{ }^{1}$

Porthanin arkkuun kätketty jäämistö sai odottaa 1900-lukua, ja useaan kertaan 1800-luvun kuluessa uumoiltiin, millaisia aarteita suurmiehen salaiset paperit sisältäisivätkään. Juuri 1800-luvulla Porthanin perintöä vaalittiin erityisen voimakkaasti, ja fennomaaninen liike asetti hänet yhdeksi esikuvakseen, suurmieheksi. 1850-luvulla yleistyi tapa kutsua Porthania Suomen historian isäksi, "den finska historiens fader". Porthanin kirjoitusten uudelleenjulkaisu alkoi vuonna 1859 nimellä Opera selecta, ja

\footnotetext{
${ }^{1}$ Hannu Salmi, "Porthanin arkku ja historian perintö", Auraica. Scripta a Societate Porthan Edita (6) 2015, s. 21-32, https://journal.fi/aur/article/view/53500.

${ }^{2}$ Litteraturblad för allmän medborgerlig bildning 8, 1853; Helsingfors Tidningar 12.11.1853; Helsingfors Tidningar 26.4.1853; Helsingfors Tidningar 25.2.1857; Finland Allmänna Tidning 26.2.1857; Åbo Tidningar 3.3.1857; Åbo Underrättelser 3.3.1857; Wiborg 23.12.1859; Vasabladet 31.12.1859. Suomenkielisestä lehdistöstä, ks. Suometar 22.5.1857.
} 
tämä työ jatkui vuoteen $1873 .^{3}$ Myöhemmin Porthanin tuotannon julkaisua jatkoi Turussa vuonna 1936 perustettu Porthan-seura.

Suomalaisen Kirjallisuuden Seura kunnioitti 1800-luvulla Porthania ja painotti hänen merkitystään määrittelemällä vuosijuhlapäiväkseen Porthanin kuolinpäivän 16. maaliskuuta. Jatkossa juuri Suomalaisen Kirjallisuuden Seura oli keskeisiä Porthanin perinnön vaalijoita. Vuonna 1854 seura teki aloitteen muistomerkin perustamiseksi suurmiehen haudalle. Tosin hautapaikasta ei Turun palon jälkeen ollut täyttä varmuutta. Paljon debattia herätti myös kysymys siitä, pitäisikö muistomerkkiä ylipäätään rakentaa Turkuun vai olisiko sen paikka Helsingissä. Lopulta muistomerkistä sukeutui patsashanke, ja tänään tuo jyhkeä pronssipatsas kohoaa nimenomaan Turussa, Porthaninpuistossa. Patsaan tärkeimpiä puuhamiehiä oli Fredrik Cygnaeus (18071881), Keisarillisen Aleksanterin yliopiston estetiikan ja nykykansain kirjallisuuden professori. Teoksen veisti Carl Eneas Sjöstrand (1828-1906), ja se valettiin Münchenissä, Baijerissa, josta se vaivalloisesti kuljetettiin Suomeen. Patsaan paljastustilaisuus koitti 9. syyskuuta 1864. Näyttävää juhlaa saatteli 65 kanuunanlaukausta, Porthanin elinvuosien merkkinä. ${ }^{4}$ Patsas on Suomen vanhin henkilömonumentti, ja se oli syntyessään ainutlaatuinen historiakulttuurinen teko.

Patsas on tunnetuin, ja muistetuin, 1860-luvun muistomerkki Porthanille, mutta samaan aikaan syntyi myös musiikillinen teos, jonka historiallinen muistijälki on jäänyt hauraammaksi. Porthan-huuman tuloksena syntyi ajatus sävellyksestä, joka kiinnittäisi huomiota sekä "Suomen historian isän" perintöön että konkreettiseen patsashankkeeseen, johon tarvittiin varoja. Tämän tuloksena syntyi Fredrik Cygnaeuksen kirjoittama ja Fredrik Paciuksen (1809-1891) säveltämä kantaatti Henrik Gabriel Porthan, jota kutsutaan myös Porthan-kantaatiksi ja joka sai kantaesityksensä keväällä 1860. Tämän artikkelin tavoitteena on selvittää unohdetun sävellyksen syntyä, sen tulkintaa Porthanista sekä teoksen vastaanoton historiaa. Millainen oli Paciuksen ja Cygnaeuksen tulkinta ja mitä teoksen vaikutushistoria voisi kertoa Porthanin paikasta kulttuurisessa muistissa?

\section{Kantaatin synty}

Ajatuksen Porthan-aiheisesta sävellyksestä esitti Fredrik Cygnaeus, runoilija ja kriitikko, joka oli Porthan-kultin keskeisiä arkkitehtejä. Hän oli rehevä, dynaaminen, monipuolinen persoona, joka tunsi opiskeluajaltaan Runebergin, Snellmanin,

\footnotetext{
${ }^{3}$ Eero Matinolli, "H. G. Porthanin muistopatsaan syntyhistoria", Turun Historiallinen Arkisto XVI. Artturi H. Virkkusen syntymän 100-vuotismuistoa 19.1.1964 kunnioittaen, Turun Historiallinen Yhdistys,

Turku, 1963, s. 203-213.

${ }^{4}$ Matinolli, "H. G. Porthanin muistopatsaan syntyhistoria", s. 203-213; Irma Sulkunen, Suomalaisen Kirjallisuuden Seura 1831-1892, Suomalaisen Kirjallisuuden Seura, Helsinki, 2004, s. 116-117; Matti Klinge, Mikä mies Porthan oli?, Suomalaisen Kirjallisuuden Seura, Helsinki, 1989, s. 94-97.
} 
Nervanderin ja Lönnrotin. ${ }^{5}$ Hän oli myös Fredrik Paciuksen ystävä ja yhteistyökumppani, ja he olivat toteuttaneet nimenomaan näyttäviä kantaatteja, Festsång vuonna 1851 Aleksanterin kunniaksi järjestettyyn akateemiseen juhlaan, kantaatin "Den sista, tysta kampen slutad var" vuonna 1855 Nikolai I:n kuoleman johdosta sekä kantaatin De hemlösa vuonna 1858 Uudenkaupungin suurpalon uhrien muistoksi. ${ }^{6}$ Cygnaeus oli kokenut akateemisen tilapäärunouden taitaja, jonka kynästä kirposi promootiorunoja ja säkeitä väittelijöiden kunniaksi. Tosin hänen helmasyntinään pidettiin monimutkaisia lauserakenteita, joiden vuoksi tekstin virtaavuus kärsi. ${ }^{7}$

Cygnaeus oli jo vuonna 1839 kirjoittanut runon "Porthans namn", jonka Fredrik Ehrström sävelsi ylioppilaiden laulettavaksi Porthanin syntymän satavuotisjuhlaan. ${ }^{8}$ Pidemmän, yhdeksänsäkeistöisen tekstin hän kirjoitti vuonna 1859, ajatuksena, että se juhlistaisi Porthanin syntymän 120-vuotisjuhlaa saman vuoden marraskuussa. Tuomi Elmgren-Heinosen Pacius-biografian mukaan "Cygnaeus ehdotti Paciukselle konsertin järjestämistä sekä juhlarunon säveltämistä tilaisuutta varten". ${ }^{9}$ Matti Vainio puolestaan toteaa, että Cygnaeus teki ehdotuksensa vuoden 1859 lopulla, ${ }^{10}$ mikä tarkoittaa, että aikaa sävellystyöhön olisi ollut kovin vähän.

Vaikka kaksikko oli tehnyt yhteistyötä useaan otteeseen 1850-luvulla, yhteinen taival ei ollut ongelmaton. Pacius oli ammattitaitoinen säveltäjä, joka oli saanut oppinsa Louis Spohrin ja Moritz Hauptmannin johdolla Kasselissa. ${ }^{11}$ Hänen voittokulkunsa oli 1850-luvulla kiistatonta: takana oli Maamme-laulun suurmenestys sekä oopperan Kaarle-kuninkaan metsästys (Kung Karls jakt) juhlittu kantaesitys vuonna 1852. Yhteistyö Cygnaeuksen kanssa vakiintui 1850-luvulla, ehkä juuri siksi, että Cygnaeus sanoitti runoillaan julkisia seremonioita, joiden säveltäjäksi Pacius Suomen johtavana tekijänä oli itseoikeutettu. Sekä Elmgren-Heinonen että Vainio ovat todenneet ne suuret vaikeudet, jotka Paciuksella oli ymmärtää Cygnaeuksen mutkikkaita säkeitä. Pacius koki Cygnaeuksen tyylin ylisanaiseksi ja niin yleväksi, että sitä oli vaikeaa säestää musiikillisesti. Otteen piti olla niin grandiöösi, etteivät Helsingin resurssit sitä aina mahdollistaneet. Yhteistyön vaikeus ilmeni jo vuonna 1855, kun Pacius sävelsi surukantaattia Nikolai I:n kuoleman johdosta. Vainio siteeraa Paciuksen kirjettä Cygnaeukselle:

\footnotetext{
${ }^{5}$ Matti Berger, "Esipuhe”, teoksessa Fredrik Cygnaeus, Kirjoituksia kirjallisuudesta 1837-1873. Suomentanut ja toimittanut Martti Berger, Artemisia, Firenze, 2007.

${ }^{6}$ Matti Vainio, Pacius. Suomalaisen musiikin isä. Atena, Jyväskylä 2009, 450, 452-453.

${ }^{7}$ Johan Wrede, "Estetik och litteraturhistoria", Finlands svenska litteraturhistoria. Första delen: Åren 1400-1900. Utgiven av Johan Wrede, Svenska litteratursällskapet i Finland, Helsingfors, 1999, s. 294.

${ }^{8}$ Fredrik Cygnaeus, Samlade arbeten. Poetiska arbeten. Tredje bandet, G. W. Edlunds förlag, Helsingfors, 1885, s. 93-94.

9 Tuomi Elmgren-Heinonen, Laulu Suomen soi... Fredrik Pacius ja hänen aikansa, Oy Fazerin musiikkikauppa, Helsinki, 1959, s. 337.

${ }^{10}$ Vainio, Pacius, s. 321.

${ }^{11}$ Elmgren-Heinonen, Laulu Suomen soi..., s. 29-38; Tomi Mäkelä, Fredrik Pacius, kompositör i Finland, Svenska litteratursällskapet i Finland, Helsingfors, 2009, s. 65-69.
} 
En voi olla vihainen sinulle, mutta olen varsin äkämystynyt itselleni, kun suostuin ottamaan vastaan tehtävän, josta minun olisi jo etukäteen pitänyt tietää, etten siitä ikinä kunnolla selviä. Minulla ei ole ollut vaikeuksia ainoastaan sinun sanojesi tähden, joita minun on työlästä säveltää, vaan nykyisten esitysmahdollisuuksien vuoksi! Tällaisella kurjalla, kurjalla, kurjalla orkesterilla soitettuina sinun salamoittesi, ilotulitustesi, niin ... syntyy täysi fiasko! Äläkä luule, että lasken tässä leikkiä, tämä on kuoleman vakavaa, kun ajattelen, että minä yksin joudun seisomaan häpeäpaalussa koko tämän kurjuuden tähden. ${ }^{12}$

Cygnaeuksen mutkikkaat lauserakenteet aiheuttivat Paciukselle päänvaivaa, mikä ilmeni myöhemmin myös Porthan-kantaatin kohdalla, mutta kyse oli myös siitä, millainen mielikuvitusmaailma runoihin sisältyi. Pacius viittaa "salamoihin" ja "ilotulituksiin": jos tällaiset ilmiöt esiintyivät runokielessä, niihin piti myös vastata musiikin keinoin. Runouden konstikkuutta Pacius kommentoi myös Porthan-kantaatin kohdalla. Maria Collan-Beaurainin Pacius-elämäkerran mukaan säveltäjä oli tokaissut: "Huru vill du att jag skall sätta dessa förbannade ord i musik?”13

\section{"Missä yö oli vallinnut - uusi päivä koitti"}

Porthan-kantaatista on säilynyt käsinkirjoitettu partituuri sekä Sibelius-museon arkistossa $^{14}$ että Kansalliskirjastossa. ${ }^{15}$ Partituuria, sen paremmin kuin orkesteristemmojakaan, ei ole koskaan julkaistu painettuna. ${ }^{16}$ Pacius kirjoitti teoksen suurelle orkesterille, jossa oli jousiston, ensimmäisen ja toisen viulun, alttoviulun, sellon ja kontrabasson lisäksi puhallinsoittimia, kaksi huilua, oboe, kaksi klarinettia, fagotti, kaksi käyrätorvea, kaksi trumpettia ja kolme pasuunaa sekä lisäksi patarummut. Lauluosuudesta vastasi teoksessa sekakuoro, ja Pacius kirjoitti äänet sopraanolle, altolle, tenorille ja bassolle. Tämän lisäksi Pacius päätti käyttää resitatiivia, eli sävellyksessä oli kertoja, joka lausuu osan Cygnaeuksen tekstistä. Nämä valinnat ovat jo itsessään olennaisia teoksen luonteen kannalta. Samaan aikaan kun kuoro antoi teokselle potentiaalin mahtipontisuuteen, varsinkin loppuhuipennuksessa, resitatiivin kautta Pacius pystyi loihtimaan herkkiä sävyjä. Ehkäpä hän tämän kautta tavoitteli myös yksilön ja yhteisön välisen suhteen dynamiikkaa. Sekakuoron käyttäminen ei sinänsä ollut poikkeuksellista, sillä Pacius oli hyödyntänyt myös aiemmissa kantaateissaan yhtä aikaa mies- ja naiskuoroa. Isänmaalliset tunteet on usein liitetty mieskuorolaulun

\footnotetext{
${ }^{12}$ Cit. Vainio, Pacius, s. 277.

${ }^{13}$ Maria Collan-Beaurain, Fredrik Pacius, lefnadsteckning, Söderström, Helsingfors, 1917.

${ }^{14}$ Fredrik Pacius, H.G.Porthan. Nuottikäsikirjoitus, Åbo Akademin arkistokokoelmat, Sibelius-museo.

${ }^{15}$ Fredrik Paciuksen arkisto, luettelo 169, Kansalliskirjasto, https://www.doria.fi/bitstream/handle/10024/94628/169\%20Pacius.pdf, haettu 2.12.2019.

${ }^{16}$ Keväällä 2019 Asko Kuusilehto puhtaaksikirjoitti ja editoi Sauli Huhtalan avustuksella stemmat kantaatin esitystä varten. Tämä toteutui Turun yliopiston ja Åbo Akademin yhteisenä akateemisena päivänä 26. maaliskuuta 2019. Akademiska Orkesternia johti Sauli Huhtala, ja kuoro-osuuden esittivät Florakören ja Brahe Djäknar. Puheosuuden esitti Jacob Waselius.
} 
nousuun ja suosioon 1800-luvulla, mutta sekakuorollakin oli paikkansa yhteisöllisyyden kuvaajana. Mies- ja naiskuoroja oli käytetty niin kirkollisissa kuin maallisissakin sävellyksissä ja toki myös oopperakirjallisuudessa, joka oli Paciukselle tuttua. Samaan aikaan sekakuoroa suosivat monet kantaattisäveltäjät, muun muassa puolalainen Stanisław Moniuszko (1819-1872). ${ }^{17}$ Kuten Celia Applegate on todennut, kuoromusiikilla oli erityisesti 1800-luvulla tärkeä merkitys paitsi yhteisöllisyyden kuvaajana myös sen rakentajana. Vuosisata oli laulujuhlien, festivaalien ja kuorotapahtumien aikaa. ${ }^{18}$ Pacius oli itse käyttänyt oopperan sekakuoroa Kaarlekuninkaan metsästyksen loppukohtauksessa kuningastaan tervehtivän kansan mikrokosmoksena. Säveltäjän 1850-luvun kantaateissa sekakuorolla oli samanlainen yhteisöllisyyttä korostava asema.

Toinen strateginen valinta Porthan-kantaatissa liittyy kertojan käyttöön. Nykykuulijasta tämä saattaa tuntua vieraalta, sillä kertojan käyttö väheni musiikissa merkittävästi 1800-luvun jälkeen. Lausujaa pidettiin 1800-luvulla melodraaman tunnusmerkkinä. Melodraamat olivat useimmiten piano- tai orkesterisäestyksellisiä teoksia, joissa tekstiä ei laulettu vaan lausuttiin. Tällaisia olivat esimerkiksi Franz Lisztin melodraamat "Leonore" ja "Der traurige Mönch". ${ }^{19}$ Melodraaman tausta oli kuitenkin syvemmällä, tragedian ja oopperan historiassa, ja oopperakirjallisuudesta tunnetaan paljon melodraaman käyttöä laajempien teosten osana. Paciuksen tiedossa olivat epäilemättä kauhuromanttiset tunnelmat Beethovenin Fideliossa (1805) ja Carl Maria von Weberin Taika-ampujassa (Der Freischütz, 1821). Hyvin Weber-henkisesti Pacius hyödynsi melodraamallista kerrontaa Kaarle-kuninkaan metsästyksessä. Porthankantaatissa tavoitteet olivat kuitenkin kaikkea muuta kuin kauhuromanttiset, vaikka tunteisiin vetoamista Pacius varmasti tavoitteli. Siirtymät kuoron eeppisemmästä kerronnasta yksilön kokemuksiin painottivat jännitettä Porthanin järisyttävän elämäntyön ja hänen arkisen nöyrän työskentelynsä välillä.

Paciuksen Porthan-kantaatti, joka on kestoltaan noin 15 minuuttia, jakaantuu kolmeen osaan. Alun keveä kesäinen kuva muuttuu vakavammaksi teoksen keskivaiheilla, joka sisältää melodramaattisen resitointijakson. Lopussa kantaatti kohoaa C-duuriin ja loppuu majesteetillisiin fanfaareihin. Matti Vainion tulkinnan mukaan alku on "pääasiassa perinteistä luonnonkuvausta, jota Pacius kuvittaa herkin ja valoisin orkesterivärein". ${ }^{20}$ Teoksen alussa viulujen, alttoviulujen ja sellojen staccatot johdattelevat aurinkoiseen tunnelmaan con moto, "liikkuvasti", As-duurissa, ja kun kuoron sopraanot ja altot aloittavat Cygnaeuksen tekstin, lauluosuus vahvistaa kesäpäivän kuvaa:

\footnotetext{
${ }^{17}$ Judith Mabary, "The Czech Lands: Bohemia and Moravia", Nineteenth-Century Choral Music, ed. Donna M. Di Grazia, Routledge, New York, 2013, s. 384.

${ }^{18}$ Celia Applegate,"The Building of Community through Choral Singing", Nineteenth-Century Choral Music, ed. Donna M. Di Grazia, Routledge, New York, 2013, s. 5-10.

${ }^{19}$ Melodramas for piano and narrator. Music by F. Liszt, R. Strauss and D. Milhaud, Carleton Sound CSCD-1015.

${ }^{20}$ Vainio, Pacius, s. 321.
} 
Fjäriln med sommarstrålarna leker,

Lefver med stunden och bortförs med den;

Smekes af vinden och blommorna smeker,

Sviker sin kärlek, sjelf sviken igen.

Vingen af skiftande färgspelet glänser,

Lik en mot jorden sväfvande sky:

Trånga dock, fjäril, äro de gränser

Hvarur du fåfängt söker att fly. ${ }^{21}$

Idyllinen kuva luonnosta tiivistyy päiväperhon lyhyeen elämään. Perhonen leikkii auringon lämpimissä säteissä, elää tässä ja nyt, tuulten hyväilemänä, kukasta kukkaan lentäen. Värikkäät ovat perhosen siivet ja niiden hohde, mutta lopultakin sen elämä on vain rajallista. Pacius toistaa ensimmäisen säkeistön kaksi viimeistä säettä "Trånga dock, fjäril, äro de gränser / Hvarur du fåfängt söker att fly" ja luo crescendon kautta odotuksen käänteestä. Sopraanot ja altot siirtyvät toiseen säkeistöön:

Regnbäcken sorlar, gör mycket väsen

Af sina svällande krafters försök,

Krafterna tyna dock bort förr än gräsen,

Sjelf han försvinner lik dimma och rök;

Lemnar knappt efter sig spår i den sanden,

Uti hvars fåror ett lif han ej väckt:

Sorlet ej följes af genljud i landen

Mera än vårens hviskande flägt.

Perhosen rinnalle asettuvat luonnonilmiöt. Sateen synnyttämä puro lirisee äänekkäästi, mutta sen voimat eivät riitä kaivertamaan syvempää jälkeä, eikä vesi jätä kuin vaatimattoman uurteen hiekkaan. Puron pulina ei lopulta kaiu kauemmaksi vaan jää kevään heikoksi kuiskaukseksi. Kuoron pianissimo saattelee säettä "Krafterna tyna dock bort förr än gräsen”, mutta niin laulu kuin orkesterikin kohoavat forteen toiseksi viimeisessä säkeessä "Sorlet ej följes af genljud i landen", aivan kuin Pacius haluaisi kaiuttaa juuri nämä sanat konserttisaliin, kuin enteeksi siitä merkityksellisestä elämäntyöstä, joka kohta olisi tulossa areenalle. Perhoseen ja puroon liittyvien tuokiokuvien jälkeen kantaatti siirtyy toiseen jaksoon, mihin viittaa myös partituurin merkintä allegro moderato con fuoco, joka taittuu pian allegron kautta moderatoksi. Samalla sävellaji vaihtuu E-duuriin. Seuraa komparatiivinen jakso, jossa Cygnaeus nostaa esille luonnon sijaan hengen. Samassa kohdassa myös kuoron sukupuoli vaihtuu. Jos luonnonkuvat alkoivat sopraanojen ja alttojen äänellä, kansakunnan henkiä kommentoivat bassot:

\footnotetext{
${ }^{21}$ Runo on julkaistu Cygnaeuksen kootuissa teoksissa: Fredrik Cygnaeus, arbeten. Poetiska arbeten. Tredje bandet, G. W. Edlunds förlag, Helsingfors, 1885, s. 94-97.
} 
O! Huru annorlunda är verket

Af dessa andar, nationerna ställt

Såsom det säkra, det ledande märket

Vid horizonten af sanningens fält.

De ej af fjärlarna afspegla färgen,

Ej deras lif liknar regn bäckens dans;

Men hvad de ville står fast såsom bergen,

Och hvad de gjort, liksom polstjernans glans.

Säkeistön neljä ensimmäistä säettä ovat bassojen laulamia, ja niiden jälkeen tenorit jatkavat kohdassa "De ej af fjärlarna afspegla färgen”. Korkeampi ääniala, tenori, viittaa alun luonnonkuvaan, perhoseen ja puroon. Neljännen säkeistön alku asettaa selvästi "kansakuntien henget" luonnon hetkellisyyttä vastaan: totuus siintää horisontissa, ja se, mitä henget luovat, seisoo kuin vuori ja loistaa kuin pohjantähti. Muutosta ennakoi myös sävellajin vaihdos, kirkkaus ja selkeys, kun kohdassa "Men hvad de ville står fast såsom bergen" sävellajiksi asettuu C-duuri. Viidennessä säkeistössä Cygnaeus nostaa jalustalle sen mittavan elämäntyön, jonka Porthan oli tehnyt:

En sådan ande, Finlands folk,

I din Porthan du haft.

Den blef emellan dig en tolk

Och minnet, som gömts utan kraft

I tidernas förfallna graf.

Åt Finska häfdens spridda drag

Han sammanhang och klarhet gaf:

Der natten rådde, grydde dag.

Pacius käyttää kuoron dramaattista tehoa taitteen merkkinä. "En sådan ande, Finlands folk, / I din Porthan du haft" kajahtaa niin sopraanojen ja alttojen kuin tenorien ja bassojen laulamana. Porthan on vastaus kysymykseen siitä, kuka voisi olla vakaa kuin vuori ja jättää jäljen tuleville polville. Kaksi ensimmäistä säettä paisuvat korostetuksi toteamukseksi, väitteeksi, joka huipentaa sävellyksen keskiosan. Fermaatin jälkeen seuraa resitatiivijakso, ja lausuja esittää koko viidennen säkeistön ilman kuoron tai orkesterin läsnäoloa. Pacius-elämäkerrassaan Matti Vainio ei pidä ratkaisua kovin kekseliäänä, sillä hänen mukaansa jaksossa "pyritään kuvaamaan Porthania itseään ja hänen työtään suomalaisen kulttuurin mahtimiehenä muun muassa melodraaman avulla, kun säveltäjä ei muutakaan ratkaisua siihen hätään keksinyt”. ${ }^{22}$ Tämä voi tietysti pitää paikkansa siinä mielessä, että Pacius on onnistunut sijoittamaan suurimman osan Cygnaeuksen tekstisisällöstä resitatiiviosuuteen ja pystynyt painottamaan haluamiaan säkeitä. Lausuntajakson alussa Pacius ei itse asiassa nojaudu melodraamaan siinä mielessä, että orkesteri loisi tunnelmaa sanoille, vaan orkesteri esittää välikkeen, joka johtaa säkeistöstä toiseen. Näin teos etenee kahden lisäsäkeistön verran:

\footnotetext{
${ }^{22}$ Vainio, Pacius, s. 321.
} 
Hans arbete, det gick ej lätt,

Och när hans lif gick allrabäst,

Det fåror i hans panna skar,

Och mödan var dess hvardagsgäst.

Men fast hans skuldra kände tungt,

Att seklers hedersskuld den bar,

I honom lefde sinnet ungt

Bland hopen än af ålderns dar.

Och fädrens skuld betalte han,

Liksom på spel hans ära stått.

Der svedjeländer fordom man

Och striders fält uppsökte blott,

Ett fosterland, ett framtidshopp,

All kärlek värdt, han såg,

Och fostrade till tanke opp,

Hvad som i känslans vagga låg.

Cygnaeus kuvaa Porthanin työn vaikeuksia, jotka saivat hänen otsansa uurteille. Koko vuosisadan taakka oli hänen harteillaan, mutta hänen mielensä oli nuorekas ja hän katsoi kunniakseen vastata aiempien sukupolvien haasteeseen. Tässä kohtaa sanat suuntautuvat tulevaisuuteen, aivan kuin Porthan olisi nähnyt sen kehityksen, joka synnytti Suomen: "Ett fosterland, ett framtidshopp..." Nyt Pacius nojautuu oopperalliseen kokemukseensa ja tehostaa melodramaattisuutta säestämällä runoa musiikillisesti. Cygnaeus ja Pacius johdattavat kuulijan menneisyyteen, Porthanin aikaan, hänen majaansa, ja runon kolme viimeistä säkeistöä luovat affektiivisen kuvan vaatimattomasta suurmiehestä, joka ponnisteli kotimaansa hyväksi. ${ }^{23}$ Orkesteri osallistuu aktiivisesti runon tunnelman rakentamiseen:

Ensam stod han i sin hydda,

Fast han dit till sällskap lockar

Andar ifrån tider, flydda;

Fast kring honom städs sig skockar

Ungdom, slägte efter slägte;

Fast ej fanns en vrå af landet,

Dit hans visdoms ord ej räckte

Och från hjertat gångna bandet.

Han, den ensamme i lifvet,

Har ännu dock slägt och vänner

I hvart bröst, hvaråt blef gifvet

\footnotetext{
${ }^{23}$ Matti Klinge on viitannut Cygnaeuksen puheeseen Porthanin patsaan paljastustilaisuudessa syksyllä 1864. Cygnaeus totesi Porthanin edustavan "työn kunniaa, ahkeruutta". Klinge, Mikä mies Porthan oli?, s. 101.
} 
Hjerta och det klappa känner.

Vid de namnen: Finland, Finne,

Är Porthans olösligt knutet;

När det dött i folkets minne,

Är det sjelft ej långt från slutet.

Än de lefva likväl båda;

Bilden af sitt lif, sin ära

I Porthans vårt land vill skåda,

Den skall mägtigt vittne bära

Inför hela efterverlden,

Att vi ej med tomma orden

Vägt omäteliga värden,

Som gjort dyrbar fosterjorden.

Toiseksi viimeisen säkeistön kohdalla Pacius säestää sanoja "Finland" ja "finne" orkesterin forte-iskuin. Resitatiivijakson jälkeen seuraa kantaatin päätös, jonka karakterisointina on partituurissa maestoso, "majesteetillisesti". Pacius on ratkaissut Cygnaeuksen runon käsittelyn palaamalla juhlavassa lopetuksessa viidenteen säkeistöön "En sådan ande, Finlands folk", johon koko kuoro yhtyy. Tuomi Elmgren-Heinonen kuvaa lopetusta: "Viimeisessä maestosossa hän [Pacius] lisää orkesteriinsa runsasta värikkyyttä johtaakseen lopun mahtavasti kohoavaan nousuun: 'Missä yö oli vallinnut uusi päivä koitti'."24

\section{"Isänmaallisuuden lämmin henkäys"}

Alkuperäinen ajatus oli juhlistaa sävellyksellä Porthanin syntymän 120-vuotisjuhlaa marraskuussa 1859, mutta kantaesitys viivästyi seuraavan vuoden puolelle. Tällä ei sinänsä ollut merkitystä, koska perimmäisenä motiivina oli rahoituksen, ja huomion, kerääminen patsashankkeelle. Teos pääsi yleisön eteen vasta, kun Porthan-kantaatti sai ensi-iltansa Keisarillisen Aleksanterin yliopiston juhlasalissa 16. maaliskuuta 1860, Porthanin kuolinpäivänä. Ohjelmassa kuultiin myös muuta musiikkia. Avausnumerona oli Luigi Cherubinin alkusoitto oopperasta Lodö̈ska. Tätä seurasivat Ludwig van Beethovenin Elegischer Gesang sekakuorolle ja orkesterille, Wolfgang Amadeus Mozartin säveltämä sopraanoaaria, kaksi suomalaista laulua mieskuorolle, ruotsalainen ylioppilaslaulu sekä sopraanoaaria Felix Mendelssohnin oratoriosta Paulus. Näiden musiikkinumeroiden jälkeen seurasi juhlapuhe, jonka piti professori Wilhelm Lagus. Papperslyktanin mukaan esitelmä oli oppinut katsaus "af bildhuggarekonsten och dess användande till nationella monumenter" ${ }^{25}$

\footnotetext{
${ }^{24}$ Elmgren-Heinonen, Laulu Suomen soi..., s. 339.

${ }^{25}$ Helsingfors Tidningar 17.3.1860; Papperslyktan 19.3.1860.
} 
Konsertin huipennuksena oli Paciuksen kantaatti, jota yleisö oli varsinaisesti saapunut kuulemaan. Sanomalehdistössä kiinnitettiin erityistä huomiota kuoroon, sillä se oli ennennäkemättömän laaja. Papperslyktan kirjoitti jo ennen konserttia 20. helmikuuta: "Fruntimmer, studenter, handelsbiträden, handtverkare, allt hvad i staden sjungande finnes, skall förenas till en kör, hvars like man ännu aldrig här har hört." ${ }^{26}$ Myös muissa lehdissä kuoron valtavuus tuotiin esiin jo etukäteen. ${ }^{27}$ Åbo Underrättelser ennakoi 8. maaliskuuta 1860, että lavalla nähtäisiin peräti 250 laulajaa. ${ }^{28}$ Lopulta kuoroon osallistui arvioiden mukaan lähes 300 laulajaa. ${ }^{29}$ Valtava kuoro oli mikrokosmos oman aikansa yhteiskunnasta: ylioppilaskuoron lisäksi lavalla oli naiskuoro, mutta myös kauppaapulaisten lauluseura, käsityöläiskuoro sekä koululaisista koottu lapsikuoro. ${ }^{30}$ Koska naislaulajia oli vähän, täydennettiin sopraanoja lapsilla. Suomen musiikkilehti haastatteli vuonna 1937 valtionarkistonhoitaja Reinhold Hausenia (1850-1942), joka oli koko elämänsä ajan innokas kuorolaulaja. Hausen oli 10-vuotiaana mukana Porthankantaatin esityksessä. Hän muisteli:

Olin silloin koulupoika, tarvittiin kuoroon miesten lisäksi koulupoikia "naisääniä" laulamaan - naisethan eivät siihen aikaan vielä yleisesti ottaneet osaa kuoroihin, sekakuoroja nykyaikaisessa mielessä ei ollut - ja niin minäkin jouduin mukaan sopraanoa laulamaan. Kuoro ja orkesteri esittivät Paciuksen johdolla kantaatin, joka alkoi "En sådan ande i din Porthan du haft". Juhlan tarkoituksena oli koota varoja Turkuun pystytettävää Porthanin patsasta varten ja eiköhän niitä mahtanutkin kertyä. ${ }^{31}$

Hausen viittaa sekakuorojen puutteeseen instituutiona, mutta kantaatin esitykseen riittävä määrä sopraanoja saatiin kokoon. Papperslyktan kuvasi esityskoneistoa 19. maaliskuuta:

Elementarskolornas och lycei små friska sångarkörer i främsta ledet, bakom dem fruntimrens svartklädda rader, längre bort studenternes, handelsbiträdenas och handtverkarnes sångföreningar, broderligt blandade tillsammans, och högst uppe på estraden den manstarka orkestern - alla samlade de sina toner till den oförgätlige fosterlandsvännens lof, sången klingade herrligt och starkt, och en varm flägt af patriotism gick kanske genom alla åhörares hjertan. ${ }^{32}$

Kuten lehti totesi, "isämaallisuuden lämmin henkäys" kosketti kuulijoiden sydämiä, ja varmasti tähän tunteeseen vaikutti se kokemus, jonka mittava kuoro, miesten, naisten ja lasten yhteinen esitys sai aikaan. Orkesteriakin oli vahvistettu tavanomaisesta, jotta

\footnotetext{
${ }^{26}$ Papperlyktan 20.2.1860

${ }^{27}$ Åbo Underrättelser 23.2.1860; Åbo Tidningar 24.2.1860.

${ }_{28}$ Åbo Underrättelser 8.3.1860.

${ }^{29}$ Papperlyktan 19.3.1860.

${ }^{30}$ Elmgren-Heinonen, Laulu Suomen soi..., s. 339; Vainio, Pacius, s. 322. Ks. myös Helsingfors Tidningar 17.3.1860.

31 "Vanha laulaja kertoo", Suomen musiikkilehti 1/1937, s. 9.

${ }^{32}$ Papperlyktan 19.3.1860.
} 
Paciuksen muhkea orkestraatio olisi päässyt oikeuksiinsa. Kantaattiin sisältyvän puheosuuden esitti lehtitietojen mukaan ylioppilas Wecksell..$^{33}$ Arviossa ylioppilasta ei tarkemmin nimetty, mutta yliopiston vuosien 1853-1899 matrikkelissa ainoa 1850luvulla kirjautunut Wecksell oli Josef Julius Wecksell (1838-1907), myöhempi näytelmäkirjailija, joka oli kirjautunut yliopistoon syyskuussa $1858 .{ }^{34}$

Esityksessä haluttiin korostaa Cygnaeuksen sanojen merkitystä. Ne painettiin ohjelmalehtiseen, jotta yleisö pystyi seuraamaan kappaletta ja ehkä vielä myöhemminkin pohtimaan Porthanin merkitystä. Lehtisestä on säilynyt kappale Åbo Akademin pienpainatekokoelmassa. ${ }^{35}$

Kaiken kaikkiaan Porthan-kantaatin esitys oli valtaisa menestys, josta sanomalehdet kertoivat seuraavina päivinä kautta maan. Uutisissa todettiin muun muassa, että kantaatin loppukuoro piti esittää uudelleen, niin innostunutta yleisö oli. "Konserten för Porthans minnesstod var på samma gång en musik- och nationalfest”, kirjoitti Finlands Allmänna Tidning 19. maaliskuuta 1860. "Den vackra imposanta chören af den ovanligt talrik skara sångerskor och sångare, gjorde på åhörarne ett mäktigt intryck. Ett skallande bifall, egnadt ej mindre sångens innehåll än den herrliga musiken, genljöd i salen så snart de sista tonerna tystnat. Att ej alla, som skulle önskat, kunde erhålla inträdeskort för konserten, i anseende till bristande utrymme, var att förvänta." ${ }^{36}$

Helsingfors Tidningar puolestaan kuvaili ensi-iltaa seuraavana päivänä 17 . maaliskuuta:

I går den 16 mars var konserten så talrikt besökt, som solennitetssalens utrymme medgaf, och alla inträdeskort redan i thorsdags försålda. Anblicken af den stora estraden, der kören, sångerskor och sångare, stod i täta mörka leder framför den amfitheatraliskt placerade orkestern, gjorde en vacker effekt Musiken isynnerhet sången - svarade mot det lifvande intrycket af det hela. Hr Pacius stod der som en fältherre i spetsen för den talrikaste musikaliska armé, som Helsingfors någonsin skådat på engäng församlad, och förde med säker hand sin mäktiga marskalksstaf. ${ }^{37}$

Porthan-kantaatin menestys kantoi vielä seuraavaan vuoteen, jolloin se esitettiin Helsingissä Porthanin syntymäpäivän muistoksi 9. marraskuussa 1861 . $^{38}$ Tällä kertaa kertojan roolin esitti lehtitietojen mukaan "Collan"39, arvattavasti Karl Collan (18281871), josta oli vuonna 1859 tullut yliopiston saksan kielen lehtori ja josta viisi vuotta

\footnotetext{
${ }^{33}$ Helsingfors Tidningar 29.3.1860.

${ }^{34}$ Ylioppilasmatrikkeli 1853-1899, https://ylioppilasmatrikkeli.helsinki.fi/1853-

1899/aakkosittain.php?init=w, haettu 2.12.2019.

${ }^{35}$ Den 16 mars 1860. J. C. Frenckell \& Son, Helsingfors, 1860, Åbo Akademin pienpainatekokoelma, http://bibbild.abo.fi/smatryck/16\%20mars\%201860.pdf, haettu 2.12.2019.

${ }^{36}$ Finlands Allmänna Tidning 19.3.1860.

${ }^{37}$ Helsingfors Tidningar 17.3.1860.

${ }^{38}$ Helsingfors Tidningar 9.11.1861.

${ }^{39}$ Finlands Allmänna Tidning 11.11.1861.
} 
myöhemmin tuli Paciuksen vävy. ${ }^{40}$ Myös suomenkielinen lehdistö noteerasi esityksen. Suomen Julkisia Sanomia kirjoitti 14. marraskuuta 1861:

Mutta sitten saatiin vielä suureksi riemuksi kuulla saman laulu-soitelman Henrik Gabriel Porthan, joka ensikerran kuultiin samanlaisessa juhlassa 1 p. maaliskuuta 1860, johon professorit Cygnaeus teki sanat ja Pacius soiton, molemmat jaloja teoksia, ja yhdistettynä sanomattomasti mieltä ylentäviä ja ihastuttavia. Sekä nuorukaiset ja neidot että lapset ja soittajisto, kaikki yhdistiwät ääniänsä. - Lastenkin suusta isänmaan-tunto ja -rakkaus valmisti voiman ja kiitoksen. ${ }^{41}$

Porthan-juhlijoiden yhteenkuuluvuutta korostettiin ympäri Suomea, ja tilaisuuksista kertovia uutisia kopioitiin lehdestä toiseen. Kun Turussa vietettiin Porthan-juhlaa 9. marraskuuta, Helsingin Porthan-juhlan osallistujat lähettivät Turkuun sähkeen: "Lefwe Porthan och gamla Åbo." 42

Porthan-kantaatin suurin menestys jäi vuosiin 1860 ja 1861, mutta sillä oli olennainen merkitys innostuksen nostattajana. Porthan oli säännöllisesti esillä myös sanoma- ja aikakauslehdistössä, muulloinkin kuin kantaatin yhteydessä. Aikakauden tunnetuimpia tekstejä oli Johan Vilhelm Snellmanin Literaturbladissa syyskuussa 1861 julkaisema kirjoitus "Hvad var Porthan?" Snellman korosti Porthanin suomalaisuutta: "Porthan före och framom alla sina samtida fattades af denna 'osynliga ande', den Finska folkanden, om hvilken ofvan talades, och att han främst och klarast fattade." ${ }^{43}$

Snellmanin hengennostatus vaikutti kouriintuntuvasti Porthanin syntymäpäivän juhlallisuuksissa marraskuussa 1861, jolloin myös Paciuksen kantaatti esitettiin uudelleen. Innostus sai huomiota jopa Suomen rajojen ulkopuolella. Lontoolainen The Morning Chronicle kirjoitti 3. joulukuuta 1861:

Meanwhile a great festival has been held in Helsingfors, an anniversary in honour of Henrik Gabriel Porthan, a man of colossal learning, the pride of Finland in the last century, and who devoted all his life and soul and fortune to the history and annals and literature of his country. He was the Camden of Finland. His memory is now honoured in a thousand ways, for history is fatherland and freedom, in a land under the Cossack yoke. Upwards of a thousand people - as many as could find room in the great University Hall took part in the proceedings, which ended with the song, 'Porthan', composed in 1860 by Cygnaeus and Pacius, and 'Our Land', the famous national Hymn of

\footnotetext{
${ }^{40}$ Esko Häkli, "Collan, Karl”, Kansallisbiografia-verkkojulkaisu, Studia Biographica 4, Suomalaisen Kirjallisuuden Seura, Helsinki, 1997, https://kansallisbiografia.fi/kansallisbiografia/henkilo/4433, haettu 4.12.2019.

${ }^{41}$ Suomen Julkisia Sanomia 14.11.1861.

${ }^{42}$ Åbo Underrättelser 12.11.1861; Finlands Allmänna Tidning 16.11.1861. Vainio mainitsee, että Porthankantaatti olisi esitetty myös Turussa (Vainio, Pacius, s. 323), mutta en ole pystynyt tätä esitystä aikalaislähteistä varmistamaan. Turun Porthan-juhlassa kuultiin kyllä muutoin komea musiikkiohjelma. ${ }^{43}$ J.V.S.: "Hvar var Porthan?", Litteraturblad för allmän medborgerlig bildning 1.9.1861, s. 386-391.
} 
Finland, an elegant and faithful translation of which appeared in the London Illustrated News some years ago. ${ }^{44}$

Kuten voidaan nähdä, Suomen tilanne herätti kiinnostusta Englannissa, jossa Maammelaulun käännös oli julkaistu muutamaa vuotta aiemmin London Illustrated News lehdessä. Vaikka Paciuksen Porthan-kantaatin maine kiiri ulkomaille asti, vuosien 1860 ja 1861 jälkeen teos unohtui, eikä se koskaan vakiintunut ohjelmistoon. Varmasti oli kyse myös siitä, että kantaatteja sävellettiin tilauksesta, päivänkohtaisiin tarpeisiin, ja usein niiden esityskoneisto oli vaativa.

\section{Kantaatin kohtalo}

Fredrik Cygnaeuksen kirjoittama ja Fredrik Paciuksen säveltämä kantaatti Henrik Gabriel Porthan syntyi 1850- ja 1860-lukujen taitteen Porthan-huumassa. Teoksella oli ensiesityksen innostuneesta vastaanotosta huolimatta välineellinen luonne: se oli tarkoitettu herättämään huomiota ja avustamaan keräyksessä, jonka päämääränä oli muistomerkin pystyttäminen. Sävellys eli kulttuurisessa muistissa vielä joitakin vuorikymmeniä, kunnes se painui unholaan.

Digitoidut sanomalehtiaineistot antavat mahdollisuuden seurata kantaatin vaiheita myöhemmin 1800-luvulla ja 1900-luvun alussa. Näyttää ilmeiseltä, että Paciuksen sävellys sai useita esityksiä Vaasassa 1890-luvulla, ainakin vuosina 1892, 1895 ja 1897.. ${ }^{45}$ Kantaatti esitettiin muun muassa 14 . joulukuuta 1895 Otto Walleniuksen johdolla. ${ }^{46}$ Pohjalainen-lehti kirjoitti esityksestä 17. joulukuuta: "Sekä orkesterin että köörin esitykset otettiin mieltymyksellä vastaan ja erityisellä mielihyvällä kuunneltiin Paciuksen kantaattia H. G. Porthan, joka yhä entisyyden kuvana viehättää." ${ }^{47}$ Silmiinpistävää on, että 25 vuotta kantaesityksen jälkeen teos näyttäytyi nimenomaan "entisyyden kuvana". Kuulijat olivat etääntyneet siitä maailmasta, jota Cygnaeus ja Pacius kuvasivat. Teos esitettiin Vaasassa uudelleen puolitoista vuotta myöhemmin, 10. huhtikuuta 1897, jolloin Fredrik Cygnaeuksen teksti kuultiin suomeksi. ${ }^{48}$ Pohjalainen julkaisi esityspäivänä koko suomennoksen lukijakunnalleen. Sen ensimmäinen säkeistö kuultiin konsertissa näin:

Perho, se suvituulessa liehuu

Valossa päivän ja leikkien vain

Lempensä vaihtuu

Kuin kukkasten lempi.

Pian se haihtuu

Min pettäen sai.

\footnotetext{
${ }^{44}$ The Morning Chronicle 3.12.1861.

${ }^{45}$ Wasa Tidning 10.1.1892, Wasabladet 14.12.1895, Wasa Nyheter 10.4.1897.

${ }^{46}$ Wasabladet 14.12.1895, Wasa Tidning 14.12.1895, Pohjalainen 17.12.1895.

${ }^{47}$ Pohjalainen 17.12.1895.

${ }^{48}$ Pohjalainen 10.4.1897, Wasa Nyheter 10.4.1897.
} 
Siivet auringon paistehessa

Kiiltävät kullan vertaisina.

Mutt' ahdas, oi perho, on alasi aivan

Ja toimesi kevyt - niin vallan mitätön.

Lehden mukaan teksti oli "erään täkäläisen soitannon ystävän suomentama". ${ }^{49}$ Vaasan esitysten jälkeen Porthan-kantatti näyttää nousseen parrasvaloihin vuonna 1909 Viipurissa, tälläkin kertaa suomennettuna. Esityksiä oli ainakin 18. maaliskuuta ja 27. huhtikuuta $1909 .^{50}$ Viipuriin liittyy myös Sibelius-museon kokoelmissa säilynyt kantaatin vokaaliosuuksien nuotti, johon on käsin kirjoitettu suomennostekstiä. ${ }^{51}$ Tämä teksti on päivätty kymmenen vuotta myöhemmin, 27. helmikuuta 1919 Viipurissa, mutta on epävarmaa, onko kyse samasta käännöksestä. Tekstin tekijäksi on kreditoitu Toni Kanzler. ${ }^{52}$ Suomennos poikkeaa vaasalaisesta tekstistä, ja sen ensimmäiset säkeet ovat:

Perhonen päivän säteissä lentää

elää vaan hetken ja taas katoaa

Keinussa tuulen se kukkihin lentää

lumoihin lemmen se sortuvi taas. ${ }^{53}$

Autonomian ajan lopulla Porthan-kantaatti sai siis esityksiä Helsingin ulkopuolella, Vaasassa ja Viipurissa, mutta merkkejä esityksistä ei enää itsenäisyyden ajalta juurikaan löydy, ainakaan sanomalehtiarkiston kokoelmista. Harvinainen poikkeus oli Bengt Carlsonin johdolla Helsingissä 1. huhtikuuta 1927 toteutettu konsertti. ${ }^{54}$ Seuraavana päivänä Helsingin Sanomat antoi siitä suhteellisen nuivan arvion: "Teoksen herättämä mielenkiinto on nykyjään yksinomaan historiallista laatua, mutta juuri siltä kannalta sitä mielikseen kuuntelikin." ${ }^{55}$ Aika tuntui ajaneen kantaatin, ja ehkä myös Henrik Gabriel Porthanin muiston, ohi.

Ystäviä Paciuksen sävellyksellä tosin oli. Tuntematon musiikinystävä lahjoitti "till Svenska Folkskolans Vänner (...) 15,000 mark för utgivande av Fredrik Pacius' otryckta vokalkompositioner". Tämän tuloksena Alfred Anderssén, monipuolinen musiikko ja Åbo Underrättelserin pitkäaikainen kriitikko, teki kantaatista nuottijulkaisun, jossa kuorostemman lisäksi oli säestys pianolle sovitettuna. Nuotti julkaistiin Svenska Folkskolans Vännerin Körbibliotek-sarjassa vuonna $1926 .{ }^{56}$ Orkesterin säestyksellä

\footnotetext{
${ }^{49}$ Pohjalainen 10.4.1897.

${ }^{50}$ Työ 18.3.1909, Wiipuri 27.4.1909.

${ }^{51}$ Porthan-kantaten (1860). Åbo Akademin arkistokokoelmat, Sibelius-museo.

${ }^{52}$ Kanzler oli viipurilainen muusikko. Ks. myös Viipurin osoite- ja ammattikalenteri. N. A. Zilliacus tryckeri, Viipuri 1904, digi.kansalliskirjasto.fi/aikakausi/binding/1262860?term=Kanzler\&page=168, haettu 4.12.2019.

${ }^{53}$ Porthan-kantaten (1860), Åbo Akademin arkistokokoelmat, Sibelius-museo.

${ }^{54}$ Uusi Suomi 30.3.1927.

${ }^{55}$ Helsingin Sanomat 2.4.1927.

${ }^{56}$ Fr. Pacius, H. G. Porthan. Kantat för kör och orkester, Svenska folkskolans vänners förlag, Helsingfors, 1926. Julkaisuja on kaksi, joista toisessa on kuorostemmat, toisessa myös pianosäestys.
} 
teosta ei Bengt Carlsonin vuoden 1927 esityksen jälkeen kuitenkaan, nykytiedon valossa, 1900-luvulla kuultu.

Porthan-kantaatin vastaanoton muutokset liittyvät epäilemättä Porthanin muuttuvaan asemaan suurmiehenä ja suomalaisen kulttuurin esikuvana. Matti Klinge on korostanut niin Fredrik Cygnaeuksen kuin J. V. Snellmanin ristiriitaista suhdetta suurmieheyteen. Cygnaeus ja Snellman eivät halunneet korostaa aikalaisiaan, mutta menneisyydessäkään ei ollut paljoa ammennettavaa. "Siinä vaiheessa, jolloin Suomi kipeästi tarvitsi omaa historiaa ja oman suurmiehen", kirjoittaa Klinge, "Porthan soveltui kansallisen jatkuvuuden symboliksi". ${ }^{57}$ Porthan-kantaatti oli saanut ensiesityksensä vuonna 1860, tilanteessa, jossa tällaisen symbolin tarve oli polttava. Puoli vuosisataa myöhemmin, Suomen siirryttyä itsenäisyyden aikaan, maailma oli kuitenkin muuttunut. Porthanin muisto oli haurastunut, eikä kantaatille enää löytynyt yleisöä.

Porthan-seuran aloitteesta Paciuksen kantaatti sai vihdoin tuoreen esityksen keväällä 2019. Sauli Huhtala ja Asko Kuusilehto rekonstruoivat ja puhtaaksikirjoittivat partituurin ja stemmat, ja teoksen esittivät Akademiska Orkestern Sauli Huhtalan johdolla sekä Brahe Djäknar ja Florakören Ulf Långackan johtamana. Puheosuuden esitti Jacob Waselius. Esitys toteutui Akatemiatalon juhlasaliassa Turun yliopiston ja Åbo Akademin yhteisenä akateemisena päivänä 26. maaliskuuta 2019.

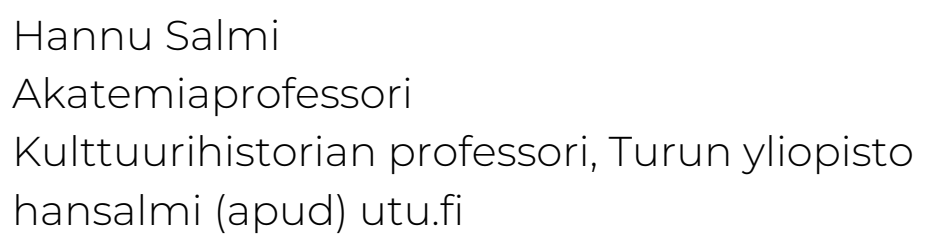

\footnotetext{
${ }^{57}$ Klinge, Mikä mies Porthan oli?, s. 104.
} 